\title{
Extended Shelf Life and Quality of Fresh-cut Papaya Derived from Ripe Fruit Treated with the Ethylene Antagonist 1-Methylcyclopropene
}

\author{
Muharrem Ergun', Donald J. Huber², Jiwon Jeong, and Jerry A. Bartz ${ }^{3}$ \\ Horticultural Sciences Department, Institute of Food and Agricultural Sciences, University of Florida, \\ 1213 Fifield Hall, Gainesville, FL 32611
}

\begin{abstract}
AdDitional INDEX WORDs. Carica papaya, color, electrolyte leakage, fresh-cut, senescence, softening, water soaking
Aвstract. The purpose of the present study was to investigate the role of ethylene action, via use of the ethylene antagonist 1-methylcyclopropene (1-MCP), on the senescence and quality of fresh-cut ripe papaya (Carica papaya $\mathrm{L}$. 'Sunrise Solo') fruit. Ripe papaya fruit were treated with $2.5 \mu \mathrm{L} \cdot \mathrm{L}^{-1} 1-\mathrm{MCP}$ and immediately processed into fresh-cut slices or left intact. At 2-day intervals over 10 days at $5{ }^{\circ} \mathrm{C}$, continuously stored slices were monitored for ethylene production, firmness, electrolyte leakage, color, sensory changes, and pathogen incidence. Slices freshly prepared from intact fruit stored under identical conditions were measured similarly. Ethylene production did not differ significantly between the treatments, although production rates were slightly but consistently higher in slices from intact control compared with intact 1-MCP-treated fruit. Mesocarp firmness of continuously stored slices and slices from fruit stored intact was significantly retained by 1-MCP. Firmness of continuously stored slices from 1-MCP-treated fruit declined $50 \%$ compared with $75 \%$ for control slices. Firmness of fresh-cut slices prepared from intact control and 1-MCP-treated fruit at each sampling interval declined $26 \%$ and $15 \%$, respectively. Electrolyte leakage remained low and changed little in slices freshly prepared from fruit stored intact. Leakage from continuously stored papaya slices increased after 4 days, and after 6 days controls increased significantly compared with stored slices derived from papaya fruit initially treated with the ethylene antagonist. The flesh color of continuously stored slices or slices prepared from fruit stored intact was influenced by 1-MCP only during the later periods of storage. Microbial counts in stored slices or slices prepared at each sampling were generally unaffected by 1-MCP. Informal sensory analysis indicated that the edible shelf life was 6 days in stored slices from 1-MCP-treated fruit compared with 2 to 3 days for stored slices from control fruit.
\end{abstract}

Freshly harvested, ripe papaya fruit typically exhibit a storage potential of less than one week under ambient tropical conditions (Paull et al., 1997; Sankat and Maharaj 1998). The high perishability of papaya and other tropical fruit is further exacerbated when they are utilized as fresh-cut products. Karakurt and Huber (2003) reported that the deterioration of fresh-cut papaya fruit was significantly accelerated compared with intact fruit held under identical conditions. This is likely the case for most fruit, and illustrates the need to explore alternative procedures for delaying senescence or deteriorative processes in fresh-cut fruit and vegetables.

Tissue wounding as a consequence of fresh-cut processing elicits numerous physiological and biochemical changes that contribute to reduced shelf life, even at the relatively low holding temperatures (typically below $5^{\circ} \mathrm{C}$ ) for these value-added products (Watada et al., 1990, 1996). Production of ethylene increases significantly in many fresh-cut fruit and vegetables (Rolle and Chism, 1987) along with increased susceptibility to pathogenic microorganisms (Varoquaux and Wiley, 1994). Karakurt and Huber (2003) demonstrated that fresh-cut papaya fruit stored at $5{ }^{\circ} \mathrm{C}$ showed marked increases in catabolic enzymes targeting

Received for publication 27 Jan. 2005. Accepted for publication 24 Apr. 2005 This research was supported, in part, by a grant from the USDA Program in Tropical Agricultural Research (T-STAR) and from contributions from Rohm and Haas' Agro-Fresh Division and approved for publication as Journal Series No. R-10241 of the Florida Agricultural Experiment Station.

${ }^{1}$ Current address: Kahramanmaras Sutcu Imam Univ., Dept. of Horticulture, 46100 Kahramanmaras, Turkey.

${ }^{2}$ To whom reprint requests should be addressed. E-mail address: djh@mail.ifas. ufl.edu

${ }^{3}$ Plant Pathology Dept., Institute of Food and Agricultural Sciences, Univ. of Florida, 1213 Fifield Hall, Gainesville, FL 32611. membranes and cell walls, and these increases greatly exceeded those noted for intact fruit stored under identical temperatures. The accelerated deterioration of the fresh-cut compared with intact fruit is also likely a consequence of the loss of epi- and sub-epidermal tissues, which provide both physical and chemical protective attributes, and also in response to enhanced ethylene production and respiration.

The continued responsiveness of climacteric fruit to ethylene during (Tucker and Brady, 1987) and to some extent upon completion of ripening (Hoeberichts et al., 2002) would suggest that fresh-cut tissue derived from ripe fruit could benefit from exposure to antagonists to ethylene biosynthesis and/or action. Of the ethylene action inhibitors available, 1-methylcyclopropene (1-MCP) (Sisler and Serek, 1997) has proven most effective at suppressing ripening and adverse ethylene responses in numerous plant tissues (Blankenship and Dole, 2003). The compound is effective not only at delaying the onset of ripening but also in delaying the progression of ripening when applied to mid-stage ripening fruit including apple [Malus xsylvestris (L.) Mill. var. domestica (Borkh.) Mansf.] (Jiang and Joyce, 2002; Miretal, 2001; Pre-Aymard et al., 2002), and nearly full-ripe tomato (Lycopersicon esculentum Mill.) (Hoeberichts et al., 2002; Wills and Ku, 2002), watermelon [Citrullus lanatus (Thunb.) Matsum \& Nakai] (Mao et al., 2004), and papaya (Ergun and Huber, 2004) fruit.

The capacity to attenuate ripening in fruit at more advanced stages of ripening would appear to be an obligatory requirement for use with fresh-cut fruit since optimum quality can be achieved using only specimens that are ripe or nearly so at the time of processing. The temperatures $\left(\leq 5^{\circ} \mathrm{C}\right)$ typically employed for storage of fresh-cut fruit tissues are not conducive to continued development and ripening during storage. Our previous work has 
demonstrated that both pre-ripe and full-ripe intact papaya fruit exhibited significantly extended shelf life at $20{ }^{\circ} \mathrm{C}$ in response to the ethylene antagonist 1-MCP (Ergun and Huber, 2004). The purpose of the present study was to investigate the efficacy of ethylene-action suppression at influencing the rate of senescence of fresh-cut papaya tissue derived from nearly full-ripe fruit and stored at $5^{\circ} \mathrm{C}$.

\section{Materials and Methods}

Plant material. Papaya ('Sunrise Solo') fruit were obtained from C-Brand Tropicals, Homestead, Fla. Fruit treated with fungicide were shipped from Brazil by airfreight within $3 \mathrm{~d}$ after harvest and stored at $13{ }^{\circ} \mathrm{C}$. Fruit were transferred to the postharvest facilities in Gainesville, Fla., on the day of receipt and stored at $20^{\circ} \mathrm{C}$ for $1 \mathrm{~d}$. The fruit were then selected on the basis of uniformity of size and freedom from defects and graded according to surface color as an estimate of ripeness. The fruit were gently brushed, washed with tap water, immersed in chlorinated water $\left(200 \mu \mathrm{L} \cdot \mathrm{L}^{-1}\right)$ for $1 \mathrm{~min}$, dried, and treated with $1-\mathrm{MCP}$ as described below.

1-MCP TREatment. The average firmness, ethylene production, and respiration rates of the fruit measured at $20{ }^{\circ} \mathrm{C}$ immediately prior to $1-\mathrm{MCP}$ treatment were $6.8 \pm 0.7 \mathrm{~N}, 0.8 \pm 0.3 \mu \mathrm{L} \cdot \mathrm{kg}^{-1} \cdot \mathrm{h}^{-1}$, and $22 \pm 3.2 \mathrm{~mL} \cdot \mathrm{kg}^{-1} \cdot \mathrm{h}^{-1}$, respectively. Only fruit within the range of $70 \%$ to $80 \%$ surface yellow coloration were used for the treatments. 1-MCP was generated from a $0.14 \%$ powdered formulation (SmartFresh; AgroFresh, Philadelphia). Three grams of powder were placed in a $136-\mathrm{mL}$ glass vial to which was immediately added $50 \mathrm{~mL}$ of deionized water and sealed. The sealed vial was incubated on an oscillating shaker $(1.4$ cycles/s) for $1 \mathrm{~h}$. The concentration of 1-MCP in the vial headspace was measured using a gas chromatograph (model 5890; Hewlett-Packard, Avondale, Pa.) equipped with a 80-100 mesh Chromosorb PAW stainless steel column (1.8 m × $3.18 \mathrm{~mm}$ i.d.; Supelco, Bellefonte, Pa.). Injector, oven, and detector (FID) were set to 150, 70, and 200 ${ }^{\circ} \mathrm{C}$, respectively. Isobutylene, which has a FID response similar to that of 1-MCP (Jiang et al., 1999), was used to quantify 1MCP levels. 1-MCP levels in the vial headspace were $\approx 7500$ $\mu \mathrm{L} \cdot \mathrm{L}^{-1}$. A headspace volume of $3.3 \mathrm{~mL}$ was injected into $18.9-\mathrm{L}$ plastic, airtight containers (20 fruit per container), yielding a final 1-MCP concentration of $2.5 \mu \mathrm{L} \cdot \mathrm{L}^{-1}$. Exposure to $1-\mathrm{MCP}$ was maintained for $24 \mathrm{~h}$ at $20^{\circ} \mathrm{C}$. To minimize the development of modified atmospheres, the containers after $12 \mathrm{~h}$ were vented and provided with 1-MCP freshly prepared as described above. Control fruit were sealed in similar containers but not provided with 1-MCP.

FRESH-CUT PROCESSING. Immediately following treatment with 1-MCP or air (control), the papaya fruit were transferred to a $5{ }^{\circ} \mathrm{C}$ cold room, the surfaces of which had been sanitized (200 $\mu \mathrm{L} \cdot \mathrm{L}^{-1}$-chlorinated water) prior to fruit processing. After several hours at $5^{\circ} \mathrm{C}$ to allow temperature equilibration, the blossom and pedicel ends of each fruit were removed, and the fruit longitudinally cut into 1.5 -cm-thick slices (from the pedicel end to the stem end). The two outermost slices were peeled, and cut into sections with approximate dimensions of $1.5 \mathrm{~cm}$ thick $\times 3.5 \mathrm{~cm}$ wide $\times 4 \mathrm{~cm}$ long (15 to $20 \mathrm{~g}$ ). Afterward, the slices were rinsed quickly with chilled, sterile distilled $\mathrm{H}_{2} \mathrm{O}$ using a squeeze bottle, and then placed in 1.7-L vented plastic containers (FridgeSmart model 3991A-4; Tupperware, Orlando, Fla.) with molded grids on the lower surface to facilitate uniform air circulation. Relative humidity in the containers was $94 \%$ to $97 \%$. Sixty containers (30 slices each for tissue derived from control and 1-MCP-treated fruit) were used in this experiment, and 10 slices of these (five slices for each treatment) were removed at 2-d intervals for evaluation. Additionally, 80 intact fruit (40 each of control and 1-MCP-treated) were stored along with the fresh-cut tissue at 5 ${ }^{\circ} \mathrm{C}$. At intervals for measuring the continuously stored fresh-cut papaya tissue, samples of intact fruit were processed into slices as described above and measured similarly.

The treatments included fresh-cut papaya slices derived from intact fruit pre-treated with air [fresh-cut control (FCC)] or 2.5 $\mu \mathrm{L} \cdot \mathrm{L}^{-1} 1-\mathrm{MCP}$ [fresh-cut from 1-MCP-treated fruit (FCM)], and fruit pretreated with air (intact control, IC) or 1-MCP [intact 1-MCP-treated (IM)], maintained intact during storage, and processed as slices on the days of measurement. At selected intervals during storage at $5{ }^{\circ} \mathrm{C}$, ethylene production, mesocarp firmness, electrolyte leakage, color, sensory changes, and microbial growth were measured for both fresh-cut and intact fruit processed at the time of measurement. Slices prepared from intact fruit were analyzed to assist in differentiating between the effects of wounding (fruit sliced at day 0) vs. effects due to storage at $5^{\circ} \mathrm{C}$, well below the chilling injury threshold for papaya.

ETHYLENe PROduction. Ethylene production was measured by placing continuously stored fruit slices or slices prepared from intact fruit on each measurement day (four slices per fruit) in 950-mL plastic containers. The containers were sealed for 2 $\mathrm{h}$ at $5^{\circ} \mathrm{C}$, and $\mathrm{C}_{2} \mathrm{H}_{4}$ in the containers was measured using a gas chromatograph (model 5890; Hewlett Packard) equipped with an activated alumina SS column and flame ionization detector. The carrier gas (nitrogen) was $30 \mathrm{~mL} \cdot \mathrm{min}^{-1}$. Oven, injector, and detectors were operated at 200,70 , and $250{ }^{\circ} \mathrm{C}$, respectively.

Firmness. Firmness of fresh-cut slices of papaya stored at 5 ${ }^{\circ} \mathrm{C}$ was measured with an Instron Universal Testing Instrument Model 4411 (Instron Corp., Canton, Mass.) fitted with an 8-mm convex probe and 5-kg load cell. On the days for each firmness determination, samples of intact fruit were processed into freshcut slices as described above. Firmness measurements were performed at $20^{\circ} \mathrm{C}$. The convex probe was placed at zero force contact with the centermost section of the surface of each slice, and penetrated to a depth of $10-\mathrm{mm}$ at a crosshead speed of 50 $\mathrm{mm} \cdot \mathrm{min}^{-1}$. Data are reported as the maximum force (Newtons) generated during penetration of the slices.

Electrolyte leakage. Tissue cylinders (five per fruit slice) were removed from continuously stored slices and from slices derived from stored intact fruit using an 8-mm steel cork borer. The cylinders were trimmed to produce 8-mm-thick disks using the centermost region of each cylinder. The disks (five per slice) were rinsed briefly with deionized water and blotted on a slightly moistened filter paper (Whatman). The disks were incubated in $15 \mathrm{~mL}$ of $500 \mathrm{~mm}$ mannitol on an oscillating shaker at room temperature for $4 \mathrm{~h}$, followed by a conductivity measurement of the bathing solution. The aliquot removed for the conductivity measurement was returned to the bathing solution. Conductivity was measured using a conductivity bridge (Y-31A; Yellow Springs Instrument, Yellow Springs, Ohio) equipped with a conductivity cell (model 3403; Yellow Springs Instrument). Afterward, the bathing solution and disks were transferred to $-20{ }^{\circ} \mathrm{C}$ for at least $24 \mathrm{~h}$, thawed and placed into a boiling water bath for 30 min, cooled to room temperature, and conductivity of the bathing solution again measured. Electrolyte leakage was expressed as a percentage of the total tissue electrolytes, estimated from the frozen/heated samples. 
Color AND SENSORY EVALUATION. Flesh color of the centermost region of mesocarp slices was recorded as lightness $\left(\mathrm{L}^{*}\right)$, hue angle, and chroma using a Minolta Chroma Meter CR-200 (Minolta Camera Co., Tokyo). Surface-pitting on the skin of intact fruit, and water soaking on the upright (facing) surface of fresh-cut slices were graded on a numeric scale of 0 to 20 , with each number representing $\approx 5 \%$ increases in water-soaked regions (e.g., 0 for $0 \%, 1$ for $5 \%, 2$ for $10 \%$, etc.). Five slices derived from fruit stored intact were prepared on each measurement day and evaluated similarly for water soaking. Informal descriptive analysis was used to assess the quality of either stored fresh-cut slices or slices derived from intact fruit stored under similar conditions $\left(5^{\circ} \mathrm{C}\right)$ and for similar durations $(0,2,4,6,8$, and 10 d), with emphasis on overall appearance, odor, texture, and flavor (O'Connor-Shaw et al., 1994) according to the following hedonic scale: 1 = poor, 2 = poor-good, $3=$ fair, 4 = good-excellent, and $5=$ excellent. The informal descriptive analyses were performed under evaluation lights (mixture of Sylvania 60-W Plant Gro N Show incandescent bulbs along with Sylvania 40-W Blue P40B fluorescent fixtures; Osram Sylvania, Danvers, Mass.) using three replicates for each treatment.

Microbial Counts. Papaya mesocarp tissue (5 g) was removed from the innermost portion of intact fruit (IC, IM) with a steel, flame-sterilized cork borer ( $21.5 \mathrm{~mm}$ diameter) and a flame-sterilized knife, or from fresh-cut slices (FCC, FCM) with a flamesterilized knife from slices resting on sterilized aluminum foil in a microbial transfer hood. The 5-g sample was then incubated in $45 \mathrm{~mL}$ sterile phosphate buffered saline (PBS), $\mathrm{pH} 7$. The PBS and fruit tissue were vortexed at high speed for 1 min using a FisherGenie 2 Vortex (Scientific Industries, Bohemia, N.Y.), followed by 10 -fold dilutions using sterile PBS as needed. Total aerobic, Enterobacteriaceae, yeasts and molds, total coliforms, and lactic acid bacteria counts were made using $1 \mathrm{~mL}$ of the PBS extract. The plates and incubation conditions for each count were: total aerobic count, $3 \mathrm{M}$ Petrifilm aerobic count plate (3M Microbiology Products, St. Paul, Minn.), 3 d at $30^{\circ} \mathrm{C}$; Enterobacteriaceae, $3 \mathrm{M}$ Petrifilm Enterobacteriaceae count plate, $1 \mathrm{~d}$ at $30^{\circ} \mathrm{C}$; yeasts and molds, $3 \mathrm{M}$ Petrifilm yeast and molds count plate, $5 \mathrm{~d}$ at $25^{\circ} \mathrm{C}$; total coliforms, $3 \mathrm{M}$ Petrifilm coliform count plate, $1 \mathrm{~d}$ at $30^{\circ} \mathrm{C}$; and lactic acid bacteria, $3 \mathrm{M}$ Petrifilm aerobic count plate, incubation for $2 \mathrm{~d}$ at $30{ }^{\circ} \mathrm{C}$ in a 1.9 -L airtight plastic container with a Gas Pak anaerobic system envelope (Becton Dickinson and Co., Cockeysville, $\mathrm{Md}$.). The plates were prepared in a laminar-flow hood at day 0 (immediately after slicing) and after 5 and $10 \mathrm{~d}$ at $20^{\circ} \mathrm{C}$. Microbial counts were reported as log colony-forming units per gram fresh weight of tissue.

StatistiCal ANALYsis. General linear model program (PROC GLM) of SAS (SAS Institute, Cary, N.C.) and Duncan's multiple range test $(P \leq 0.05)$ were performed for randomized completeblock design in which treatments (FCC, FCM, IC, and IM) were blocks.

\section{Results and Discussion}

STORED PAPAYA SLICES AND SLICES FRESHLY PREPARED FROM INTACT STORED FRUIT. To assist in distinguishing between the contributions of wounding and storage conditions (temperature and relative humidity) to the deterioration of papaya slices, intact fruit were co-stored with the slices. At each sampling interval, intact fruit were processed as slices and subject to the same measurements employed for continuously stored slices. The concentration of 1-MCP $\left(2.5 \mu \mathrm{L} \cdot \mathrm{L}^{-1}\right)$ employed in our studies was higher than levels ( 0.5 to $\left.1.0 \mu \mathrm{L} \cdot \mathrm{L}^{-1}\right)$ typically used with fruit at early stages of ripening. Wills and $\mathrm{Ku}(2002)$ reported that 1-MCP as high as $20 \mu \mathrm{L} \cdot \mathrm{L}^{-1}$ was significantly more effective than concentrations of $0.5 \mu \mathrm{L} \cdot \mathrm{L}^{-1}$ in delaying further development of fully ripe tomato fruit. Although Hoeberichts et al. (2002) reported that lower concentrations of 1-MCP suppressed a number of ripening parameters in ripe tomato fruit, an influence at delaying continued fruit softening was considerably less evident. Since the shelf life of fresh-cut fruit is often limited by accelerated tissue softening and water soaking, we opted to use 1-MCP concentrations in excess of those typically used for pre- or partially ripe fruit.

ETHLYLENE PRODUCTION OF STORED PAPAYA SLICES AND INTACT PAPAYA PROCESSED AS SLICES ON THE DAY OF MEASUREMENT. Ethylene production rates measured at $5{ }^{\circ} \mathrm{C}$ did not differ significantly among treatments at day 1 (Fig. 1). Ethylene production increased during storage, and after $9 \mathrm{~d}$ reached values of 64 and $48 \mathrm{~nL} \cdot \mathrm{kg}^{-1} \cdot \mathrm{h}^{-1}$ for IC and IM, and 41 and $35 \mathrm{~nL} \cdot \mathrm{kg}^{-1} \cdot \mathrm{h}^{-1}$ for FCC and FCM, respectively. These values are considerably lower than the ethylene production rates reported by Paull and Chen (1997) for fresh-cut (halved) preclimacteric and postclimacteric 'Sunset' papaya. Paull and Chen (1997) held intact and processed fruit at 22 ${ }^{\circ} \mathrm{C}$, however, conditions that would increase ethylene production rates directly, and possibly produce more rapid wound responses, compared with the $5^{\circ} \mathrm{C}$ used in our studies.

Although we anticipated that wounding (fresh-cut processing) of intact fruit at each measurement interval would significantly increase ethylene production over values for fruit processed at day 0 (in which transient, wound-induced ethylene production should have subsided), slices derived from IC and IM at each measurement interval exhibited only slightly higher ethylene production compared with FCC and FCM (Fig. 1). As noted by Paull and Chen (1997), ethylene production from wounded (halved) papaya did not increase until after $4 \mathrm{~h}$, even when held at $22^{\circ} \mathrm{C}$. In our study, ethylene production rates in slices freshly prepared from intact fruit were measured at $5{ }^{\circ} \mathrm{C}$ within $2 \mathrm{~h}$ (the time held in sealed containers) of preparation.

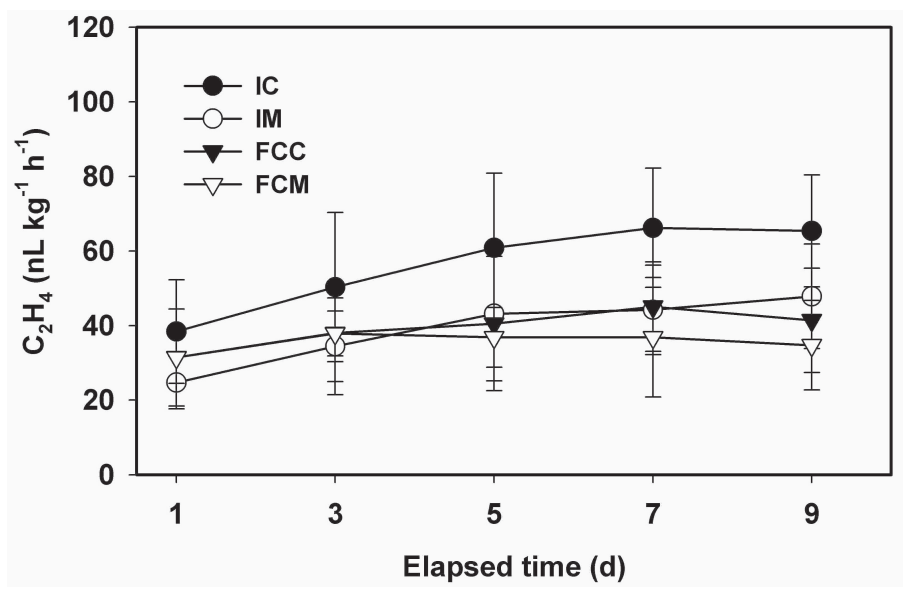

Fig. 1. Ethylene production of fresh-cut ripe 'Sunrise Solo' papaya fruit treated with $2.5 \mu \mathrm{L} \cdot \mathrm{L}^{-1} 1$-methylcyclopropene (1-MCP). Intact fruit were treated with or without $2.5 \mu \mathrm{L} \cdot \mathrm{L}^{-1} 1-\mathrm{MCP}$ and subsequently stored at $5^{\circ} \mathrm{C}$ either intact or as fresh-cut slices. A sample (five fruit) of intact fruit was processed into slices on each day of measurement. Ethylene production rates were determined at 5 ${ }^{\circ} \mathrm{C}$. IC $=$ ethylene production from slices freshly prepared from intact control fruit at each measurement (solid circle), IM = slices freshly prepared from intact 1-MCP-treated fruit (open circle), $\mathrm{FCC}=$ control fruit processed at $0 \mathrm{~d}$ and stored as slices (solid triangle), and FCM =1-MCP-treated fruit processed at $0 \mathrm{~d}$ and stored as slices (open triangle). Vertical bars represent standard deviations of the means $(n=5)$. 


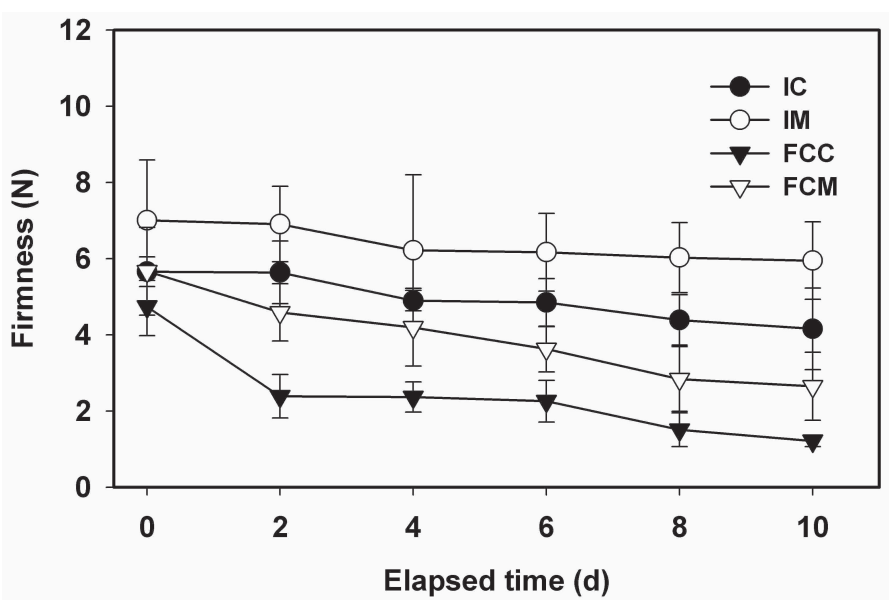

Fig. 2. Firmness of fresh-cut ripe 'Sunrise Solo' papaya fruit treated with 2.5 $\mu \mathrm{L} \cdot \mathrm{L}^{-1} 1$-methylcyclopropene (1-MCP). Intact fruit were treated with or without $2.5 \mu \mathrm{L} \cdot \mathrm{L}^{-1} 1-\mathrm{MCP}$ and subsequently stored at $5{ }^{\circ} \mathrm{C}$ either intact or as fresh-cut slices. A sample (five fruit) of intact fruit was processed into slices on each day of measurement. IC $=$ firmness of slices freshly prepared from intact control fruit ( solid circle), IM = firmness of slices from intact 1-MCP-treated fruit (open circle), $\mathrm{FCC}=$ firmness of control fruit processed at $0 \mathrm{~d}$ and stored as slices (solid triangle), FCM = firmness of 1-MCP-treated fruit processed at $0 \mathrm{~d}$ and stored as slices (open triangle). Firmness measurements were performed at 5 ${ }^{\circ} \mathrm{C}$. Vertical bars represent standard deviations of the means $(n=5)$.

The influence of the ethylene antagonist 1-MCP on ethylene production rates varies with both fruit type and maturity at the time of treatment (Blankenship and Dole, 2003), but ethylene production is generally decreased in response to 1-MCP. In the study of Paull and Chen (1997), which did not involve the use of ethylene antagonists but rather aimed to compare intact vs. processed (halved) papaya, ethylene production of processed papaya held at $22{ }^{\circ} \mathrm{C}$ increased $\approx 5$ - to 10 -fold within $4 \mathrm{~h}$ compared with intact fruit. Artes et al. (1999) reported minimal differences in ethylene production in fresh-cut, partially ripe 'Durinta' tomato fruit relative to fully intact fruit at $2{ }^{\circ} \mathrm{C}$ but 5 -fold higher production rates in fresh-cut slices compared with intact fruit at 10 ${ }^{\circ} \mathrm{C}$ (Artes et al., 1999). These studies and our data collectively indicate that the differential ethylene production rates of intact vs. fresh-cut fruit are strongly temperature dependent. Similar temperature-dependency patterns for fresh cut vs. intact fruit have been noted for respiratory rates (Watada et al., 1996).

Firmness assessment. During storage at $5^{\circ} \mathrm{C}$, papaya mesocarp firmness declined in all treatments (Fig. 2). The extent of softening was significantly $(P \leq 0.05)$ higher in FCC and FCM (continuously stored slices) compared with IC and IM (slices freshly prepared at each measurement interval), and for both treatment pairs was significantly suppressed by the ethylene antagonist 1 -MCP. Firmness of FCC declined $\approx 50 \%$, from 4.7 to $2.4 \mathrm{~N}$, during the first $2 \mathrm{~d}$ of storage, remaining constant through $6 \mathrm{~d}$, and thereafter decreasing to $\approx 1.2 \mathrm{~N}$ after $10 \mathrm{~d}$. By comparison, the firmness of FCM was significantly retained, declining only $19 \%$ (from 5.6 to $4.6 \mathrm{~N}$ ) during the first $2 \mathrm{~d}$ and, after $10 \mathrm{~d}$, retaining average firmness values of $2.7 \mathrm{~N}$, nearly 2-fold higher than values for FCC. Overall, FCC softened $\approx 75 \%$ compared with $\approx 50 \%$ for FCM over $10 \mathrm{~d}$ of storage. Firmness declines in intact fruit were considerably lower than those of continuously stored slices. IC exhibited firmness reductions of $\approx 26 \%(5.6$ to $4.1 \mathrm{~N})$ and $\mathrm{IM} \approx 15 \%(7.1$ to $5.9 \mathrm{~N})$. The absolute firmness values and relative changes in firmness for both the continuously stored slices (FCC and FCM) and freshly prepared slices (IC and IM) actually underestimate the efficacy of 1-MCP at suppressing softening in papaya. This is possibly due, in part, to the divergence in fruit firmness values between the 1-MCP-treated and control fruit during the 1-MCP exposure period (Fig. 2, this study, 0 d data; Ergun and Huber, 2004).

1-MCP suppressed the softening of both slices and intact fruit (measured on slices derived therefrom); however, the firmness of stored slices (FCC and FCM) was significantly $(P \leq 0.05)$ lower than slices (IC and IM) derived from intact fruit. The enhanced softening of continuously stored slices compared with slices freshly prepared from intact papaya might be partly due to weight (water) loss from the stored slices; however, storage duration and associated water loss of slices can not be the sole factor leading to increased softening of slices since FCM remained significantly firmer than FCC. Jeong et al. (2002) reported a delay in weight loss in intact, 1-MCP-treated avocado (Persea americana Mill.) fruit compared with controls, but this delay was correlated with the suppression of ripening in general, and overall weight loss upon reaching a full-ripe condition was identical to that of fruit not treated with the ethylene antagonist. Intact cucumber ( $\mathrm{Cucu-}$ mis sativus L.) fruit, however, which do not ripen during storage, showed significantly reduced water loss in 1-MCP-treated compared with control fruit (B. Hurr and D.J. Huber, unpublished), suggesting that suppression of ethylene perception does influence water and/or weight loss.

Factors contributing to accelerated softening of sliced vs. intact papaya and other fruit might be through active (wound-induced synthesis) or passive (activation of pre-existing, catalytically quiescent enzymes) stimulation of hydrolytic enzymes upon tissue wounding (Huber et al., 2001, 2003). Extractable polygalacturonase (EC 3.2.1.15) and $\alpha$-(EC 3.2.1.22) and $\beta$-galactosidase (EC 3.2.1.23) activities were higher in stored fresh-cut 'Sunrise Solo' papaya fruit compared with intact fruit stored under identical conditions (Karakurt and Huber, 2002). Enhanced activity of pectin hydrolases and increased pectin depolymerization upon tissue wounding have been reported by several authors (Brummell and Labavitch, 1997; Dumville and Fry, 2000; Huber and Lee, 1989; Huber et al., 2001). Wound-induced activation of cell wall hydrolases, possibly occurring in response to abrupt changes in apoplastic conditions that normally restrict in vivo hydrolysis (Almeida and Huber, 1999), could explain the enhanced softening of fresh-cut papaya (and other fruit) relative to their intact counterparts. Even so, the influence of the ethylene antagonist at suppressing softening of stored papaya slices (FCM) indicates that the ethylene-responsiveness of these enzymes remains engaged or increases, even at low temperatures $\left(5^{\circ} \mathrm{C}\right)$ (Karakurt and Huber, 2003).

Electrolyte leakage. Ion leakage from 'Sunrise Solo' papaya mesocarp tissue was relatively low (15\%) and remained nearly constant in slices derived from IC and IM (Fig. 3). Electrolyte leakage values increased in both FCC and FCM papaya at 4 through $6 \mathrm{~d}$ of storage, followed by a significant increase in leakage from FCC compared with FCM through $10 \mathrm{~d}$ (Fig. $3)$. Although electrolyte loss is considered an indirect measure of cell membrane dysfunction associated with both senescence and chilling injury in papaya and other fruit (Chen and Paull, 1986; Marangoni et al., 1996; Saltveit, 2000), tissue derived from intact papaya stored at $5{ }^{\circ} \mathrm{C}$ showed relatively low leakage values $(15 \%)$ and no change during storage. Karakurt and Huber (2003) reported that papaya slices stored at $5^{\circ} \mathrm{C}$ exhibited increased lipoxygenase (EC 1.13.11.13) and phospholipase D (EC 3.1.1.4) activities compared with slices derived from intact fruit stored under similar conditions, suggesting that membranes 


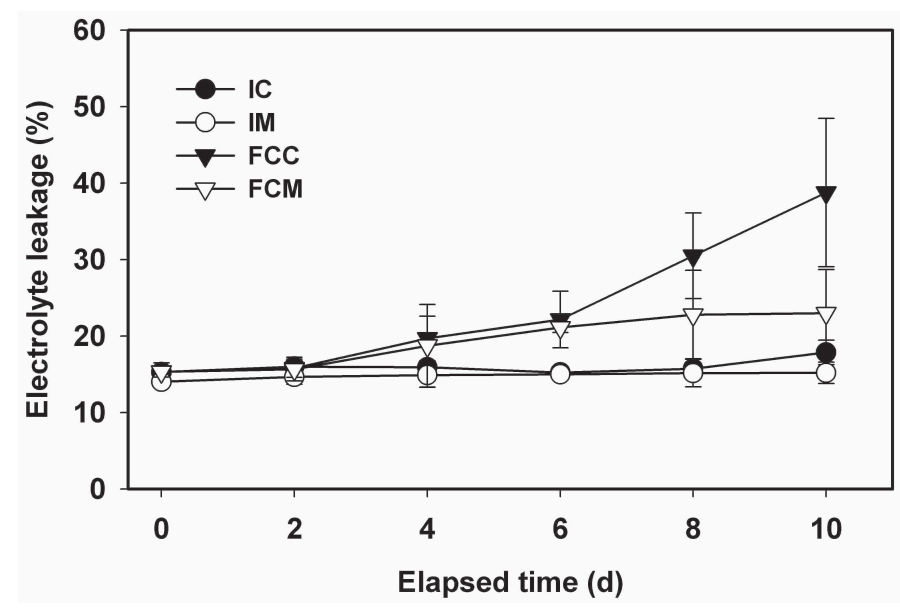

Fig. 3. Electrolyte leakage of fresh-cut ripe 'Sunrise Solo' papaya fruit treated with $2.5 \mu \mathrm{L} \cdot \mathrm{L}^{-1} 1$-methylcyclopropene (1-MCP). Intact fruit were treated with or without $2.5 \mu \mathrm{L} \cdot \mathrm{L}^{-1} 1-\mathrm{MCP}$ and subsequently stored at $5{ }^{\circ} \mathrm{C}$ either intact or as fresh-cut slices. A sample (five fruit) of intact fruit was processed into slices on each day of measurement. IC = leakage from control fruit processed into slices on day of measurement (solid circle), IM = leakage from intact 1-MCP-treated fruit (open circle), $\mathrm{FCC}=$ firmness of control fruit processed at $0 \mathrm{~d}$ and stored as fresh-cut slices (solid triangle), and FCM = firmness of 1-MCP-treated fruit processed at $0 \mathrm{~d}$ and stored as fresh-cut slices (open triangle). Vertical bars represent standard deviations of the means $(n=5)$.

were targeted in response to wounding. While membrane damage can clearly contribute to softening through loss of cell turgor, and altered apoplastic conditions, the data show no overt relationship between the initial, rapid decline in firmness (Fig. 2) and increased electrolyte leakage (Fig. 3) of FCC.

Color AND SEnSORY Evaluation. Mesocarp color scores for the continuously stored slices (FCC, FCM) and slices freshly prepared from intact fruit (IC, IM) after identical storage intervals are shown in Fig. 4 (A, B, C). As indicated by hue angle, no differences in mesocarp color were observed for any of the treatments (IC, IM, FCC, and FCM) during storage (Fig. 4B). Slight declines in $\mathrm{L}^{*}$ and chroma values were noted for FCC and FCM compared with IC, IM (Fig. 4A and 4C). The significant decline $(P \leq 0.05)$ in chroma values for the FCC compared with FCM was temporally associated with increasing evidence of water soaking. The ethylene antagonist was slightly effective at maintaining $\mathrm{L}^{*}$ and chroma values in FCM compared with values for FCC, consistent with the 1-MCP-induced suppression of water soaking in FCM compared with FCC. Beneficial effects of 1-MCP on the color properties of fresh-cut fruit have been noted for 'Golden Delicious' (Jiang and Joyce, 2002) and 'Pacific Rose' apple (Perera et al., 2003) fruit, and for pineapple [Ananas comosus (L.) Merr.] (Budu and Joyce, 2003).

Epidermal pitting, a common symptom of chill injury in papaya (Chen and Paull, 1986), was observed for the fruit stored intact but the incidence of this disorder was not influenced by the ethylene antagonist (data not shown). Water-soaked areas of mesocarp slices derived from intact fruit did not differ significantly between IC and IM and remained low, at values of $6.5 \%$ and $2.5 \%$, respectively, after $10 \mathrm{~d}$ of storage. (Fig. 5A). In contrast, water soaking of FCC and FCM increased throughout storage, with FCM displaying consistently lower incidence compared with FCC. After $4 \mathrm{~d}$ of storage, water soaking values for FCC averaged $\approx 54 \%$ compared with $28 \%$ for FCM. At day 10, FCC and FCM exhibited $96 \%$ and $76 \%$, respectively, incidence of water soaking. The increasing incidence of water soaking in the FCC and FCM tissues during storage (Fig. 5A) may represent
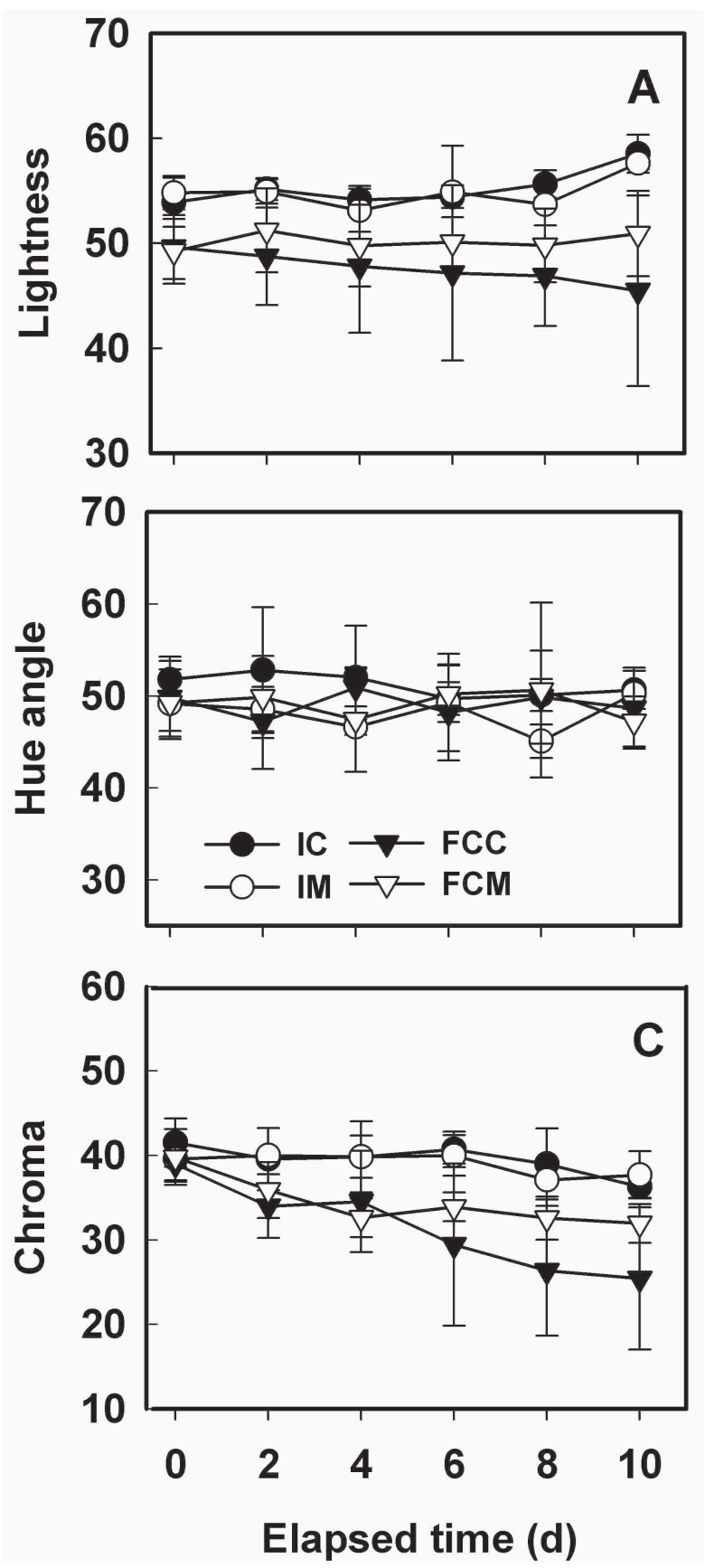

Fig. 4. Internal (mesocarp) color parameters for intact and fresh-cut ripe 'Sunrise Solo' papaya fruit treated with $2.5 \mu \mathrm{L} \cdot \mathrm{L}^{-1}$ 1-methylcyclopropene (1-MCP). Internal (mesocarp) lightness $(\mathbf{A})$, hue angle $(\mathbf{B})$, and chroma $(\mathbf{C})$ of slices derived from intact fruit at each day of measurement and from tissue stored continuously as fresh-cut slices. IC = mesocarp color parameters of control fruit processed into slices on each day of measurement (solid circle), IM = mesocarp color of intact 1-MCP-treated fruit processed into slices on days of measurement (open circle), $\mathrm{FCC}=$ mesocarp color of control fruit processed at $0 \mathrm{~d}$ and stored as fresh-cut slices (closed triangle), FCM = mesocarp color of 1-MCP-treated fruit processed at $0 \mathrm{~d}$ and stored as fresh-cut slices (open triangle). Vertical bars represent standard deviations of the means $(n=5)$.

expression of chilling injury (CI) symptoms (Chen and Paull, 1986); however, the minimal occurrence of water soaking in the mesocarp of intact fruit (IC and IM) argues against this idea. Alternatively, the fruit stored intact might have exhibited altered internal $\mathrm{O}_{2}$ (decrease) and $\mathrm{CO}_{2}$ (increase) levels, conditions known to prevent or delay the appearance of CI symptoms. The failure to develop acute CI symptoms might also be explained by the 


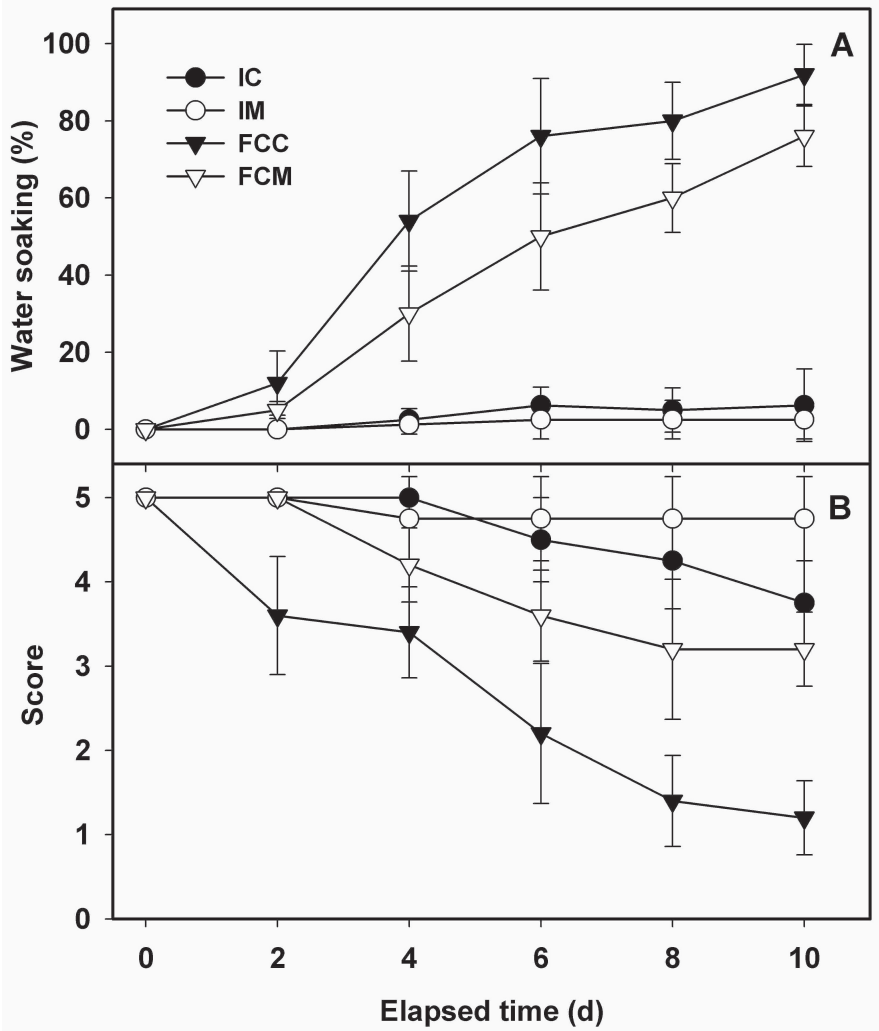

Fig. 5. Water soaking (A) and sensory evaluation (B) for fresh-cut 'Sunrise Solo' papaya fruit treated with $2.5 \mu \mathrm{L} \cdot \mathrm{L}^{-1} 1$-methylcyclopropene (1-MCP). Intact fruit were treated with or without $2.5 \mu \mathrm{L} \cdot \mathrm{L}^{-1} 1-\mathrm{MCP}$ and subsequently stored at $5{ }^{\circ} \mathrm{C}$ either intact or as fresh-cut slices. A sample (five fruit) of intact fruit was processed into slices on each day of measurement. IC = water soaking and sensory scores for intact control fruit processed into slices on days of measurement (solid circle), IM = water soaking and sensory scores for intact 1-MCP-treated fruit processed into slices on days of measurements (open circle), $\mathrm{FCC}=$ water soaking and sensory scores for control fruit processed at $0 \mathrm{~d}$ and stored as fresh-cut slices (closed triangle), and FCM = water soaking and sensory scores for 1-MCP-treated fruit processed at $0 \mathrm{~d}$ and stored as fresh-cut slices (open triangle). Vertical bars represent standard deviations of the means $(n=5)$.

full ripe condition of the fruit used in these studies. As noted by Chen and Paull (1986), papaya fruit become progressively less susceptible to visible CI symptoms with advanced ripening. Finally, fruit in the present experiments were evaluated either at or soon upon removal from the $5^{\circ} \mathrm{C}$ storage, circumventing $\mathrm{CI}$ symptoms that can require prolonged holding (days) at ambient conditions for rapid and full expression.

Tissue derived from intact papaya (IC and IM) scored over the range of 4 to 5 (good-excellent to excellent) for hedonic sensory evaluation through $6 \mathrm{~d}$ of storage, with IM retaining high scores while IC initiated a decline at $6 \mathrm{~d}$ (Fig. 5B). In contrast, FCC showed a rapid decline to values below 4 by day 2 while FCM retained a score of 5 (excellent). By $6 \mathrm{~d}$ of storage, the sensory score for FCM was 3.2 (fair to good) compared with 2.2 (poor-good to fair) for FCC. After $10 \mathrm{~d}$ of storage, FCC and FCM received ratings of $\approx 1.2$ (poor) and 3.4 (fair to good), respectively.

Microbiological counts. There was no visible evidence of microbial development on the papaya slices derived from intact fruit (IC or IM) at each measurement interval. (Table 1). The absence of microbial loads in these treatments can be explained by the fact that these fruit were surface sanitized at the start of the experiments and were not processed (sliced) until each day of measurement. In fruit surface-sanitized and processed as slices
(FCC and FCM) at the start of the experiment, microbial loads remained generally low throughout storage with the exception of total aerobic counts. Aerobic organisms increased slightly $(\approx 2$ - to 2.5 -fold) through the first $5 \mathrm{~d}$ of storage, thereafter increasing to $\log 3.43 \mathrm{cfu} / \mathrm{g}$ (day 10) and $\log 3.48 \mathrm{cfu} / \mathrm{g}$ (day 10), respectively, for the FCC and FCM (Table 1). Coliforms, Enterobacteriaceae, and molds were nearly undetectable in both intact (IC, IM) and fresh-cut (FCC, FCM) tissue throughout storage (data not shown). Yeasts were not noted in intact fruit. Although yeast counts were low in FCC and FCM, significant increases were noted at $10 \mathrm{~d}$ but were not influenced by the ethylene antagonist 1-MCP.

O'Connor-Shaw et al. (1994) reported total aerobic counts of ripe fresh-cut papaya from $\log 4.1$ to $\log 7.2 \mathrm{cfu} / \mathrm{g}$ after $4 \mathrm{~d}$ of storage at $4{ }^{\circ} \mathrm{C}$, values considerably higher than those reported in the present study after even $10 \mathrm{~d}$ of storage. The explanation for these differences is not apparent; however, O'Connor-Shaw et al. (1994) did not comment on the sanitation measures employed in their study. We anticipate that the initial microbial loads would also reflect fruit origin (region of production) as well as postharvest handling and processing procedures. Teixeira et al. (2001), who employed surface sanitation (200 $\mu \mathrm{L} \cdot \mathrm{L}^{-1}$ free chlorine) of papaya prior to processing, reported total aerobic counts of $l o g$ $3.0 \mathrm{cfu} / \mathrm{g}$ after $7 \mathrm{~d}$ of storage. These values are considerably higher than those reported here after $5 \mathrm{~d}$ of storage $(\log 1)$, but within the range of values noted here after $10 \mathrm{~d}$. The more rapid proliferation of total aerobic counts in the study of Teixeira et al. (2001) is likely explained by their storage of papaya slices at $9{ }^{\circ} \mathrm{C}$ compared with the $5{ }^{\circ} \mathrm{C}$ used in our study.

The generally lower microbial count in our studies is likely due to the combination of chlorination of intact fruit prior to processing, stringent sanitation practices during fresh-cut processing (facilities were chlorinated prior to tissue processing), and low storage temperatures $\left(5^{\circ} \mathrm{C}\right)$.

Inhibition of ethylene perception/action through use of 1MCP had no significant effect on microbial growth except for lactic acid bacteria, the growth of which seemed to be slightly promoted by 1-MCP; however, the lactic acid bacterial counts were low in all treatments, even after $10 \mathrm{~d}$ (Table 1). Intact 'Solo' papaya treated with $25 \mu \mathrm{L} \cdot \mathrm{L}^{-1} 1-\mathrm{MCP}$ at a mature-green stage and stored at $20^{\circ} \mathrm{C}$ for $20 \mathrm{~d}$ showed slightly higher symptoms of stem rots (caused mainly by Lasiodiplodia theobromae Pat.), body black rots (caused mainly by Phoma caricae-papayae Tarr. and Asperisporium caricae Speg.), and anthracnose (caused mainly by Colletotrichum Corda) compared to untreated fruit (Hofman et al., 2001). Hofman et al. (2001) speculated that the slight increase in these pathogens in 1-MCP-treated fruit was caused by a reduction in the concentrations of constitutive antifungal compounds during the extended storage periods required for these fruit to ripen. Tomato plants exposed to $10 \mathrm{~nL} \cdot \mathrm{L}^{-1} 1$-MCPexhibited a significant increase in the incidence of Botrytis cinerea Pers. proliferation in the cultivars Moneymaker and Castlemart but no increase in cultivar Pearson (Diaz et al., 2002). It would appear that the effects of suppressing ethylene perception on microbial growth in both intact and fresh-cut tissues are complex and depend upon the nature of the initial pathogen load, fruit cultivar, and tissue type and stage of development.

In conclusion, inhibition of ethylene action through short-term exposure to the ethylene antagonists 1-MCP significantly delayed quality loss of fresh-cut ripe papaya fruit stored at $5^{\circ} \mathrm{C}$, resulting in a 4-d extension in shelf life. Even in instances where extended shelf life is not a primary objective, fresh-cut tissue derived from 1-MCP-treated fruit remain firmer and of improved appearance 
Table 1. Microbial counts (log cfu/g fresh weight) for 'Sunrise Solo' papaya fruit treated with $2.5 \mu \mathrm{L} \cdot \mathrm{L}^{-1} 1$-methylcyclopropene (1-MCP) or air. Fruit were subsequently processed and stored at $5{ }^{\circ} \mathrm{C}$ either intact or as fresh-cut slices $(\mathrm{IC}=$ slices freshly prepared from intact control fruit at each measurement, $\mathrm{IM}=$ slices freshly prepared from intact 1-MCP-treated fruit, $\mathrm{FCC}=$ control fruit processed at $0 \mathrm{~d}$ and stored as slices, $\mathrm{FCM}=1$-MCP-treated fruit processed at $0 \mathrm{~d}$ and stored as slices). Means $(\mathrm{n}=3)$ followed by the same letter within a column do not differ significantly according to Duncan's multiple range test $(P<0.05)$.

\begin{tabular}{|c|c|c|c|c|c|c|c|c|c|}
\hline \multirow[b]{2}{*}{ Treatments } & \multicolumn{3}{|c|}{ Total aerobic counts } & \multicolumn{3}{|c|}{ Lactic acid bacteria } & \multicolumn{3}{|c|}{ Yeasts } \\
\hline & Day 0 & Day 5 & Day 10 & Day 0 & Day 5 & Day 10 & Day 0 & Day 5 & Day 10 \\
\hline$\overline{\mathrm{IC}}$ & $\mathrm{ND}^{\mathrm{z}} \mathrm{a}$ & ND a & $0.7 \mathrm{a}$ & $0.30 \mathrm{a}$ & $0.72 \mathrm{a}$ & $-0.16 \mathrm{a}$ & ND & ND a & ND a \\
\hline IM & ND a & ND a & $0.7 \mathrm{a}$ & $0.11 \mathrm{a}$ & $-0.15 \mathrm{a}$ & $0.82 \mathrm{~b}$ & ND & ND a & ND a \\
\hline FCC & $1.20 \mathrm{~b}$ & $1.62 \mathrm{~b}$ & $3.43 \mathrm{~b}$ & $1.05 \mathrm{~b}$ & $1.42 \mathrm{~b}$ & $1.08 \mathrm{c}$ & ND & $-0.15 \mathrm{a}$ & $1.98 \mathrm{~b}$ \\
\hline FCM & $1.16 \mathrm{~b}$ & $1.56 \mathrm{~b}$ & $3.0 \mathrm{~b}$ & $0.96 \mathrm{~b}$ & $0.43 \mathrm{a}$ & $1.25 \mathrm{c}$ & ND & ND a & $1.96 \mathrm{~b}$ \\
\hline
\end{tabular}

${ }_{\mathrm{z}} \mathrm{ND}=$ none detected.

during short-term holding. Provided that proper pre- and postprocessing sanitation practices are implemented, 1-MCP should provide more persistent quality of fresh-cut papaya.

\section{Literature Cited}

Almeida, D.P.F. and D.J. Huber. 1999. Apoplastic pH and inorganic ion levels in tomato fruit: A potential means for regulation of cell wall metabolism during ripening. Physiol. Plantarum 105:506-512.

Artes, F., M.A. Conesco, S. Hernandez, and M.I. Gil. 1999. Keeping quality of fresh-cut tomato. Postharvest Biol. Technol. 17:153-162.

Blankenship, S.M. and J.M. Dole. 2003. 1-Methylcyclopropene: Areview. Postharvest Biol. Technol. 28:1-25.

Brummell, D.A. and J.M. Labavitch. 1997. Effect of antisense suppression of endopolygalacturonase activity on polyuronide molecular weight in ripening tomato fruit and in fruit homogenates. Plant Physiol. 115:717-725.

Budu, A.S. and D.C. Joyce. 2003. Effect of 1-methylcyclopropene on the quality of minimally processed pineapple fruit. Aust. J. Expt. Agr. 43:177-184.

Chen, N.M. and R.E. Paull. 1986. Development and prevention of chilling injury in papaya fruit. J. Amer. Soc. Hort. Sci. 111:639-643.

Diaz, J., A.T. Have, and J.A.L.V. Kan. 2002. The role of ethylene and wound signaling in resistance of tomato to Botrytis cinerea. Plant Physiol. 129:1341-1351.

Dumville, J.C. and S.C. Fry. 2000. Uronic-acid oligosaccharins: Their biosynthesis, degradation and signalling roles in non-diseased plant tissues. Plant Physiol. Biochem. 38:125-140.

Ergun, M. and D.J. Huber. 2004. Suppression of ethylene perception extends shelf-life and quality of 'Sunrise Solo' papaya fruit at both preripe and ripe stages of development. European J. Hort. Sci. 69:184-192.

Hoeberichts, F.A., H.W. Linus, V.D. Plas, and E.J. Woltering. 2002. Ethylene perception is required for the expression of tomato ripeningrelated genes and associated physiological changes even at advanced stages of ripening. Postharvest Biol. Technol. 26:125-133.

Hofman, P.J., M. Jobin-décor, G.F. Meiburg, A.J. Macnish, and D.C. Joyce. 2001. Ripening and quality responses of avocado, custard apple, mango and papaya fruit to 1-methylcyclopropene. Aust. J. Expt. Agr. 41:567-572.

Huber, D.J. and J.H. Lee. 1989. Polygalacturonase activity in ripening pericarp tomato fruit determined using pericarp discs. J. Expt. Bot. 40:1331-1336.

Huber, D.J., Y. Karakurt, and J. Jeong. 2001. Pectin degradation in ripening and wounded fruits. Brazilian J. Plant Physiol. 13:224-241.

Huber, D.J., J. Jeong, and L-C. Mao. 2003. Softening of ripening fruits in response to 1-methylcyclopropene applications. Acta Hort. 628:193-202.

Jeong, J., S.A. Sargent, and D.J. Huber. 2002. Influence of 1-methylcyclopropene (1-MCP) on ripening and cell wall matrix polysaccharides of avocado (Persea americana) fruit. Postharvest Biol. Technol. 25:241-256.

Jiang, Y., D.C. Joyce, and A.J. Macnish. 1999. Responses of banana fruit to treatment with 1-methylcycloprpene. Plant Growth Regulat. 28:77-82.

Jiang, Y and D.C. Joyce. 2002. 1-Methylcyclopropene treatment effects on intact and fresh-cut apple. J. Hort. Sci. Biotechnol. 77:19-21.
Karakurt, Y. and D.J. Huber. 2002. Cell wall-degrading enzymes and pectin solubility and depolymerization in immature and ripe watermelon (Citrullis lanatus) fruit in response to exogenous ethylene. Physiol. Plantarum 116:398-405.

Karakurt, Y. and D.J. Huber. 2003. Activities of several membrane and cell-wall hydrolyses, ethylene biosynthetic enzymes, and cell wall polyuronide degradation during low-temperature storage of intact and fresh-cut papaya (Carica papaya) fruit. Postharvest Biol. Technol. 28:219-229.

Mao, L-C., Y. Karakurt, and D.J. Huber. 2004. Incidence of water-soaking and phospholipid catabolism in ripe watermelon (Citrullus lanatus) fruit: Induction by ethylene and prophylactic effects of 1-methylcyclopropene. Postharvest Biol. Technol. 33:1-9.

Marangoni, A.G., T. Palma, and D.W. Stanley. 1996. Membrane effects in postharvest physiology. Postharvest Biol. Technol. 7:193-217.

Mir, N.A., E. Curell, N. Khan, M. Whitaker, and R.M. Beaudry. 2001. Harvest maturity, storage temperature, and 1-MCPapplication frequency alter firmness retention and chlorophyll fluorescence of 'Redchief Delicious' apples. J. Amer Soc. Hort. Sci. 126:618-624.

O'Connor-Shaw, R.E., R. Roberts, A.L. Ford, and S.M. Nottingham. 1994. Shelf life of minimally processed honeydew, kiwifruit, papaya, pineapple and cantaloupe. J. Food Sci. 59:1202-1216.

Paull, R.E. and N.J. Chen. 1997. Minimal processing of papaya (Carica papaya $\mathrm{L}$.) and the physiology of halved fruit. Postharvest Biol. Technol. 12:93-99.

Pre-Aymard, C., A. Weksler, and S. Lurie. 2002. Responses of 'Anna,' a rapidly ripening summer apple, to 1-methylcyclopropene. Postharvest Biol. Technol. 27:163-170.

Rolle, R.S. and G.W. Chism. 1987. Physiological consequences of minimally processed fruits and vegetables. J. Food Quality 10:157-177.

Saltveit, M,E. 2000. Discovery of chilling injury, p. 423-448. In: S.D. King and S.F. Yang (eds.). Discoveries in plant biology, vol. 3. World Scientific Publishing, Singapore.

Sankat, C.K. and R. Maharaj. 1998. Papaya, p. 167-189. In: S. Mitra (ed.). Postharvest physiology and storage of tropical and subtropical fruits. CAB Intl., Wallingford, Oxon, U.K.

Sisler, E.C. and M. Serek. 1997. Inhibitors of ethylene responses in plants at the receptor level: Recent developments. Physiol. Plantarum 100:577-582.

Teixeira, G.H.A., J.F. Durigan, B-H. Mattiuz, and O.D. Ross, Jr. 2001. Processamento minimo de mamao 'Formaso'. Sociedade Brasileira de Ciência e Tecnologia de Alimentos. 21:47-50.

Tucker, G.A. and C.J. Brady. 1987. Silver ions interrupt tomato fruit ripening. J. Plant Physiol. 127:159-164.

Varoquaux, P. and R.C. Wiley. 1994. Biological and biochemical changes inminimally processed refrigerated fruit and vegetables, p. 226-268. In: R.C. Wiley (ed.). Refrigerated fruits and vegetables. Chapman and Hall, New York.

Watada, E.A., K. Abe, and N. Yamauchi. 1990. Physiological activities of partially processed fruits and vegetables. Food Technol. 20:120-122.

Watada, A.E., N.P. Ko, and D.A. Minott. 1996. Factors affecting quality of fresh-cut horticultural products. Postharvest Biol. Technol. 9:115-125.

Wills, R.B.H. and V.V.V. Ku. 2002. Use of 1-MCP to extend the time to ripen of green tomatoes and postharvest life of ripe tomatoes. Postharvest Biol. Technol. 26:85-95. 